\title{
金型の污染と洗浄に関する最近の動向
}

\author{
山口幸一
}

\section{Recent Trends for Mold Staining and Washing of Stained Mold}

Koichi YAMAGUCHI (Kansai Rubber Technical Training Course, 50-9 Aramoto-kita, Higashiosaka, Osaka 577-0011, Japan)

Rubber molds are widely used in the rubber industries, and the mold staining has been an important subject for a long time. This review describes the identification of the causes of mold staining, improvement of mold staining, mold releasing agent, and the washing methods of stained mold. Especially, improvements of anti-staining has been introduced by means of techniques related to rubber, various compounding ingredients, such as new material in place of zinc oxide, mold materials and the surface treatment of mold, such as coating of ceramics, nano-composite, fluoro resin and modification by ion. It has been confirmed that the suitable surface of stainless mold is obtained with increased flatness and larger contact angle of water. Various washing methods are introduced.

Key Words : Mold Staining, Surface Treatment, Contact Angle, , Mold Releasing Agent, Stainless Mold

\section{1.は じめに}

ゴム工業に扔いて，加硫・成形工程での金型污染や型離 れ不良は古くからの課題であるが，ナノテクノロジー，高 度分析機器による分析評価, シミュレーションなどの先端 ゴム関連技術が発展する中で, その対策は立ち遅れている. 金型污染が発生すると次のような問題が生じる.

・ゴム用金型の污れ(耐金型污染性)

・ゴム加硫物の不良

・ゴム加硫物の金型からの型離れ(離型性) 不良

·加硫, 成形工程の自動化への障害

・污染されたゴム用金型の洗浄が不可欠

・ゴム用金型の交換などによる加硫，成形工程の時間 ロス

・洗浄するために複数のゴム用金型が必要，コスト高 その対策のために, 污染原因・要因の解明, 金型污染入 カニズムの解明, それに伴う防止技術, 洗浄技術などがあ り，金型污染や型離机による不良を起こさないゴム材料， 各種配合剂，金型，金型表面処理技術などの開発，および 環境を考慮した仕上がりが良好で，傷の付かない金型洗浄 技術の開発が求められている.

金型污染の原因 $(\text { 表 } 1)^{1)}$ ，それに伴う污染防止技術につ いては報告されており，とくに金型污染防止技術は表 $2{ }^{2)}$ に示すようにゴム・配合片, 素練りから混練, 加硫までの 加工, 離型剤, 金型の設計・表面処理に関する方法がある.
また，污染された金型は洗浄されて使用されている.

ここでは, 最近の金型污れ防止として金型表面処理, 離 型剤，および洗浄技術に関する技術動向を紹介する.

\section{2. 金型污染の原因と防止}

\section{1 ゴム, 配合剤}

ゴムの加硫・成形は $150 \sim 210{ }^{\circ} \mathrm{C} て ゙$ 行われており, 温度

表 1 金型污染の原因

\begin{tabular}{|c|c|}
\hline ·ゴム (分子量, 触媒など) & - 加硫系 \\
\hline ·各種配合剂 & •高温時でのゴムの機械的強度 \\
\hline ·加硫条件 (温度, 時間) & ·接着剂 \\
\hline ·発泡剂 & - 防着剂 \\
\hline - 水の水質 (離型剂用, 洗浄水) & ·離型剂 \\
\hline ·金型表面の粗さ & • 金型の材質, めっき材 \\
\hline • 金型の設計 & • 金型の表面処理 \\
\hline • 金型の温度 & • 金型の大きさ \\
\hline ·作業環境 & $\begin{array}{l}\text { • 混練の加工手順, 温度, 湿度, } \\
\text { 時間 }\end{array}$ \\
\hline ·金型洗浄(洗浄度) & $\begin{array}{l}\text { - その他（練り生地の放置状態, } \\
\text { 金型の放置・管理状態) }\end{array}$ \\
\hline
\end{tabular}

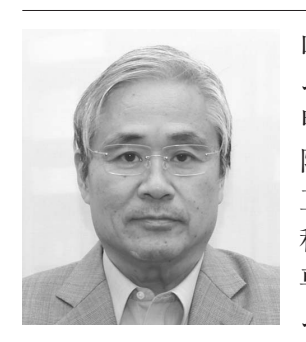

山口 幸一; 社)日本ゴム協会関西支部関西ゴ 厶技術研修所所長 (自宅)（～６63-8113 西宮市 甲子園口3-9-2). 昭和 46 年大阪市立大学大学 院博士課程修了, 工学博士. 同年, 兵庫県立 工業試験場入所. 平成 16 年退職, 財ひようご 科学技術協会をへて, 平成 19 年現職に至る。 専門は, ゴム材料, 金型, 接着技術。日本ゴ 么協会元会長, 現在評議員. 
表 2 金型污染防止技術

\begin{tabular}{|c|c|}
\hline $\begin{array}{l}\cdot \text { ゴムの改善 } \\
\cdot \text { 配合剂, 充てん剂の改善 } \\
\cdot \text { 加硫条件と管理 } \\
\cdot \text { ブレンドによる改善 } \\
\cdot \text { 防着剂の改善 } \\
\cdot \text { 水質の改良と除去 } \\
\cdot \text { 加工場所の環境 } \\
\cdot \text { 加硫, 成形工程の連続性 } \\
\cdot \text { 金型素材 } \\
\cdot \text { 金型の表面処理 (イオン注入) } \\
\cdot \text { 金型の表面処理, 被覆処理の適正化 } \\
\cdot \text { 金型の洗浄方法と管理 }\end{array}$ & 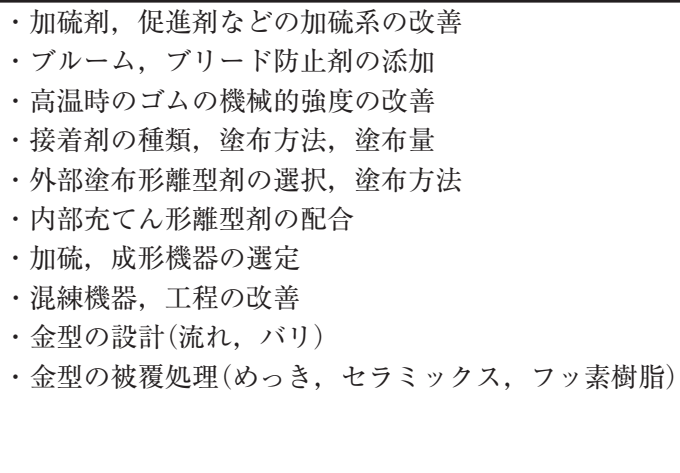 \\
\hline
\end{tabular}

表 3 ゴム配合剤一覧

\begin{tabular}{ll|l|l}
\hline \multicolumn{1}{c|}{ 配 合 剂 } & \multicolumn{1}{|c|}{ 配 合 目 的 } & \multicolumn{1}{c}{ 種 } \\
\hline 類 \\
加
\end{tabular}

が高いほど污染が発生し易く，180 ํㅡㄴㅡで污染が激しく なる．さらに，射出成形では射出圧力が高くなるほど污染 し易くなることが知られている ${ }^{3)}$ 。また，ゴムの構造，特 性と金型污染原因，改善には次の関係がある.

・ゴムの化学構造

：金型表面と密着し易いほど污染し易い

・ゴム分子中のハロゲン

：含まれるほど污染し易い

・ゴム分子中の二重結合

：含まれるほど熱劣化し，污染し易い

・ゴムに含まれる成分 (低分子量化合物, 乳化剂など)

：含まれるほど污染し易い

・ゴムの分子量

: 大きいほど污染しにくい

・ゴムの加硫挙動

: シャープな加硫 (加硫が始まると一気

に進む)ほど污染が改善

・ゴムのムーニー粘度
: 大きいほど離型性がよい

・ゴムのブレンド

: 特定の高分子材料のブレンドで污染が 改善

生産性向上に適応した高品質アクリロニトリル・ブタジ エンゴム $(\mathrm{NBR})$ が開発されており ${ }^{4)}$, 非常に優れた物性バ ランスで, 従来のNBRに比べて加硫速度が速く, シャー プであることから，金型污染も従来よりは改善される。ま た，クロロプレンゴム $(\mathrm{CR})$ に塩素化ポリエチレン $(\mathrm{CM})$ を ブレンドすることで CRの金型污染が改善されている ${ }^{5)}$. とくに，CMを未加硫で混入することが望ましく，ロール 粘着性も改善される。これは未加硫 CMの吸油性で污れを 吸収することによると考えられる。

ゴムには加硫剤, 加硫促進剂, 充てん剤, 老化防止剤, 可塑剤など表 3 に示す各種配合剤を配合しており，加硫・ 成形してゴム製品を生み出している。一般に，金型污染の 堆積物は, 硫黄, 酸化亜鉛, 加硫促進剂, 加硫促進助剂, 老化防止剂などに起因する場合が多く, 金型の曇り現象は, 
可塑剂，軟化剂，ワックス，白色充てん剤などに起因する 場合が多い。これらゴム配合剤による金型污染について， 配合剂自体が金型表面に出て污染の原因となる場合と，加 硫反応などによって配合物から生成したものが原因となっ ている場合とがある。とくに，配合剤は保管時の吸湿，凝 集などによって分散不良を起こすことが知られており，保 管時に吸湿，凝集した配合剂の分散不良が污染の原因とな り，またゴムとの相溶性が悪く，ブリード，ブルームする ものが污染を起しやすい. 加硫促進剤，可塑剂，酸化亜鉛 などが原因となるものが報告されている．

この配合剂による金型污染の改善には，次のような方法 がある。

・シャープな加硫系

・金型污染を起こさないあるいは少ない配合剤

・ゴムに対する相溶性のよい配合剂

・ゴムへの分散性を高める (配合剤の保管, 混練技術 $)^{6)}$

・ブルーム抑制剤の配合 7$)$

加硫速度が遅くなれば未加硫状態のゴムが金型へ粘着し 易いことから，金型を污染する傾向が出てくる．加硫速度 が速すぎると過加硫となり伸びの低下が生じ，型離れが悪

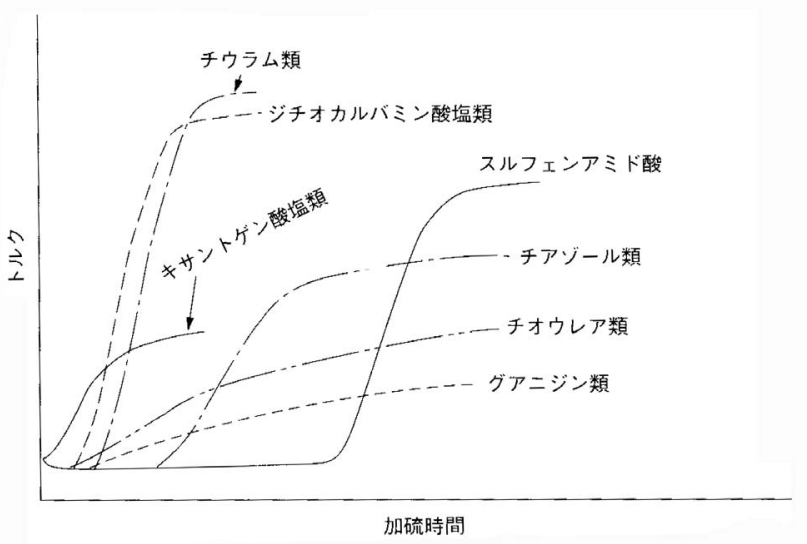

図 1 各種加硫系での加硫曲線
くなるが，加硫速度が速く，シャープであればブルーミン グ，ブリードを抑えることができる。このことから金型污 染防止には図 $1^{8)}$ に示すようにスルフェンアミド酸によ る加硫のようにシャープな加硫系が好ましい.

水素化 NBR (HNBR) の過酸化物加硫の成形工程では, 金型污染による金型離型性の悪化が原因で，離型時のクラ ック，污れの製品への転写などの不良が多発している。こ の改善として，ムーニー粘度が57.5〜 150(100 ํㅡ) 好まし くは130〜150の範囲の HNBRを使用し， ステアリン酸覀 鉛，ラウリル酸覀鉛などの脂肪酸金属塩を 2 種類以上，ま たは脂肪酸金属塩とその他の加工助剤, 滑剂を 2 種類以上 で 1 〜 部, 有機過酸化物を 3 〜 10 部配合することで達 成される ${ }^{9)}$ 。これによって金型污染が目立つまでのショッ 卜数が $20 〜 50$ から 200〜 500 になる.

酸化覀鉛は金型污れの要因の一つであることは古くから 知られており，ゴム配合物中の酸化亜鉛の量を減らすこと は金型污染の減少に有効であるとされている ${ }^{10)}$. 配合さ れている酸化亜鉛が加硫時に硫黄と反応して硫黄錯体を形 成するとされており ${ }^{11)}$, その反応は酸化亜鉛表面から起 きることが明らかにされている(図 2$)^{12)}$ 。また，ゴム中に 硫化亜鉛の微結晶が存在することが見出されている.さら に，金型污染した金型表面に生じた污染物に硫化亜鉛が存 在することが明らかにされている。これらのことから硫化 亜鉛が污染の発生に関与していることが示唆される. 従っ て，金型污染を防止するためには酸化亜鉛の配合量を減ら すことが考えられる。しかし, 酸化亜鉛は加硫助剤, 酸化 防止機能もあると言われ, 現実の問題として配合から酸化 亜鉛を減らすことは困難である，最近，酸化亜鉛を使用し なくても配合したと同等の物性が得られる酸化亜鉛に代わ るジアミンとステアリン酸の反応物 (MFA)を使用した配 合系(表 4$)^{13)}$ が発表され，この技術を活用した污染防止 が注目される。

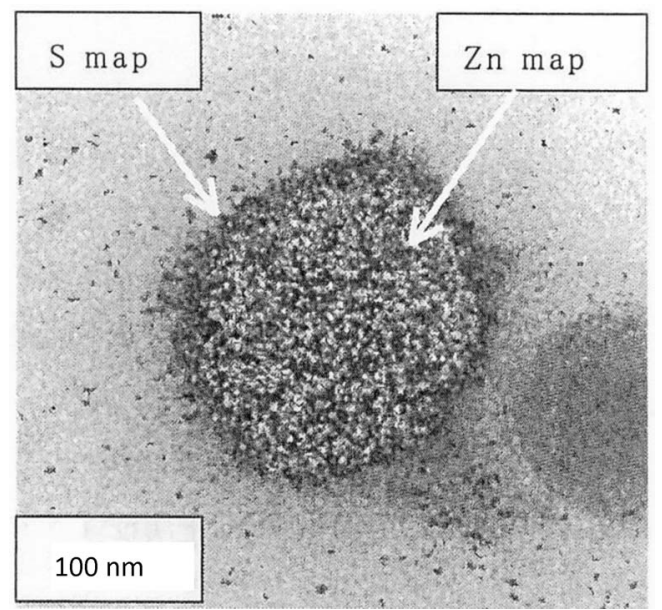

図 2 酸化亜鉛表面の吸着した硫黄 (FE-TEMマッピング像)
表 4 酸化亜鉛およびMFAによるスチレン・ブタジエンゴム加硫物の物性

\begin{tabular}{llccccc}
\hline & & $\mathrm{ZnO} / \mathrm{TBBS}$ & $\mathrm{MFA} / \mathrm{TBBS}$ & $\mathrm{MFA}$ & $\mathrm{ZnO} / \mathrm{MFA}$ & $\mathrm{ZnO} / \mathrm{MFA}$ \\
\hline$H_{\mathrm{S}}$ & ShoreA & 67 & 63 & 62 & 62 & 60 \\
$M_{25}(\mathrm{MPa})$ & 1.2 & 1 & 1.1 & 1 & 1 \\
$M_{50}(\mathrm{MPa})$ & 1.8 & 1.4 & 1.6 & 1.5 & 1.4 \\
$M_{100}(\mathrm{MPa})$ & 3.4 & 2.4 & 3 & 2.6 & 2.4 \\
$M_{300}(\mathrm{MPa})$ & 17.7 & 13.7 & 15.4 & 14.1 & 12.3 \\
$T_{\mathrm{B}}(\mathrm{MPa})$ & 21.3 & 22.3 & 23.2 & 23.3 & 15.8 \\
$E_{\mathrm{B}}(\%)$ & 345 & 428 & 413 & 440 & 357 \\
$T_{\mathrm{R}}$ & $(\mathrm{N} / \mathrm{mm})$ & 37 & 39 & 40 & 39 & 42 \\
$C S$ & $72 \mathrm{~h} / 23^{\circ} \mathrm{C}(\%)$ & 6 & 4 & 8 & 8 & 10 \\
$C S$ & $72 \mathrm{~h} / 100{ }^{\circ} \mathrm{C}(\%)$ & 35 & 27 & 37 & 33 & 39 \\
老化試験後 & $72 \mathrm{~h} / 100{ }^{\circ} \mathrm{C}$ & & & & & \\
$M_{25}(\mathrm{MPa})$ & 1.7 & 1.3 & 1.5 & 1.5 & 1.4 \\
$M_{50}(\mathrm{MPa})$ & 2.8 & 2.2 & 2.6 & 2.4 & 2.1 \\
$M_{100}(\mathrm{MPa})$ & 6.2 & 4.8 & 6 & 5 & 4.3 \\
$M_{200}(\mathrm{MPa})$ & 15.9 & 14.3 & - & 13.9 & - \\
$T_{\mathrm{B}}$ & $(\mathrm{MPa})$ & 16.6 & 15.6 & 11.5 & 16.4 & 10.2 \\
$E_{\mathrm{B}}$ & $(\%)$ & 203 & 212 & 155 & 229 & 185 \\
\hline
\end{tabular}




\section{2 金型素材, 金型表面処理}

金属素材について, 通常, S55Cなどの材料を切削加工 し，そのまま金型として使用するか，金型表面の仕上げ加 工後硬質クロムめっき，セラミックス被膜処理，フッ素樹 脂被覆などの表面処理（表 5 ) 14) を施した金型が使用され ている。しかし，これらの金型でも金型表面に污染物が堆 積するなど金型污染が起こり，型離れの不良になり，洗浄 が必要になっている。

新しい金型素材として，析出硬化系ステンレス鋼として マルテンサイト，オーステナイトまたはオーステナイト・ フェライト組織のいずれかの組織に銅元素またはアルミニ ウム元素を添加した材料が報告されている ${ }^{15)}$. 金型素材 に使用するとゴム製品の製造時における金型污染の発生を 低減し，金型洗浄を大幅に改良することができる ${ }^{15)}$ 。ブ チルゴムの圧縮成形，射出成形で，これまでの金型では 80 回程度で洗浄が必要であるが，これは 1,000 回成形でも 金型污染が認められず，この間金型洗浄が不要であった。 金型の表面処理には各種金型表面処理 (表 6$)^{16)}$ があり,

\section{表 5 現在施されているゴム用金型の表面処理}

\begin{tabular}{l|c}
\hline 金型の金属材料の表面処理 & 採用企業 $(\%)$ \\
\hline 硬質クロムめっき処理 & 34 \\
研磨, 鏡面仕上げ & 18 \\
ブラスト処理 & 15 \\
窒化処理 & 8 \\
フッ素樹脂コート & 7 \\
各種めっき処理(電気, 無電解など) & 6 \\
セラミックコート & 4 \\
(SiC, SiN, TiN, TiC, CrN, DLC, アルミナなど) & 3 \\
複合めっき処理 & 2 \\
アルマイト処理(アルミニウム合金) & 1 \\
フッ素樹脂(埋め込み)処理 & 1 \\
その他(焼き入れ，黒皮のまま) & \\
\hline
\end{tabular}

表 6 各種金型表面処理技術

\begin{tabular}{|c|c|c|}
\hline (1) & セラミックコーティング処理 & 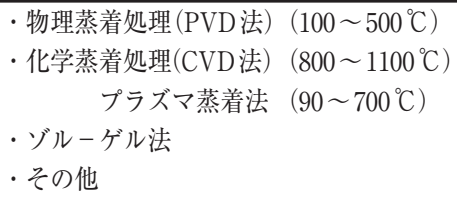 \\
\hline$(2)$ & ポリマーコーティング処理 & $\begin{array}{l}\text { · フッ素樹脂処理 } \\
\text { ·離型剂処理 } \\
\text { - その他 }\end{array}$ \\
\hline (3) & めっき処理 & $\begin{array}{l}\text { ·電気めっき } \\
\text { ·無電解めっき } \\
\text { ·無電解複合めっき } \\
\text { · その他 }\end{array}$ \\
\hline (4) & 化学処理 & $\begin{array}{l}\text { ·窒化(イオン, 軟, ガス窒化など) } \\
\text { ·侵硫 }\end{array}$ \\
\hline$(5)$ & \multicolumn{2}{|l|}{ 表面焼入れ処理 } \\
\hline (6) & \multicolumn{2}{|l|}{ 機械的処理 (ブラスト処理など) } \\
\hline (7) & \multicolumn{2}{|l|}{ プラズマ処理 } \\
\hline (8) & \multicolumn{2}{|c|}{ イオンビーム照射処理 (イオン注入) } \\
\hline (9) & \multicolumn{2}{|l|}{ 溶射処理 } \\
\hline$(10)$ & \multicolumn{2}{|l|}{ 硬質アルマイト処理 } \\
\hline (11) & \multicolumn{2}{|l|}{ 熱処理(アルミナ化) } \\
\hline
\end{tabular}

セラミックス被覆，フッ素樹脂被覆，めつき，窒化，イオ ン注入などの表面処理が実施されている.

鋼鉄，銅，真鍮などの金属表面 (アルミニウムと炭化夕 ングステンを除く)に対し電気化学的に厚さ $8 \sim 15 \mu \mathrm{m}$ で コーティングする金属表面処理法 (Vickersil)が開発されて いる ${ }^{17)}$ 。このコーティングのモルホロジーはち密なノジ ユール構造であり, 従来の硬質クロムめっきと比べ, 耐腐 蝕性・耐摩耗性に優れ, 硬度は 2 倍以上あり, 溶融樹脂・ ゴムと付着しにくく, 金型污染が少ないため, 成形品の生

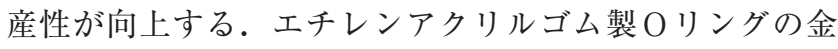
型への付着やフルオロシリコーンゴム製シールの成形への 有効性が実証されている.

タイヤトレッド成形用のアルミニウム製金型について， ナノコンポジットによる接着性のない金型コーティング法 (Kraiburgナノコンポジットコーティング法)が開発され ている18). 金型表面をシランカップリング剂で前処理し た後，ゾル-ゲル法によりナノコンポジットのコーティン グ層(厚さ $2 \sim 4 \mu \mathrm{m}$ ) を形成する. その表面はフッ素化ナ ノ粒子により接触角が大きく(表 7$)$, はっ水性となってい る.この結果, 各種ゴムの加硫・成形で優れた耐金型污染 性, 離型性を示し(表 8 ), 成形品の不良率はほぼ $0 \%$ に低 下し，離型剤の使用は少なくて済み，金型洗浄サイクル時 間は最大 3 倍まで延びる。 これらの効果は夕イヤや産業用 ゴム部品の金型にも当てはまる. 金型表面の接触角が大き

表 7 ナノコンポジットコーティング膜の表面特性

\begin{tabular}{lccc}
\hline & ナノコンポジット & PTFE & シリコーン \\
\hline 表面張力 $(\mathrm{mN} / \mathrm{m})$ & $18-22$ & $17-22$ & $17-22$ \\
接触角 $($ 水 $)(\mathrm{deg})$ & $103-107$ & $109-113$ & $111-113$ \\
接触角 $($ ヘキサン) $(\mathrm{deg})$ & $55-58$ & $56-60$ & $51-54$ \\
膜厚 $(\mu \mathrm{m})$ & $2-4$ & $>20$ & $>20$ \\
マイクロスクラッチ試験 & & & \\
$\quad$ 引っ掻き強度 $(\mathrm{MPa})$ & $181-184$ & $80-103$ & $50-53$ \\
$\quad$ 最大侵入深さ $(\mu \mathrm{m})$ & $20-25$ & $26-31$ & $52-62$ \\
表面粗さ $(\mathrm{Ra})(\mu \mathrm{m})$ & $2.9 \pm 0.2$ & $1.3 \pm 0.2$ & $0.3 \pm 0.2$ \\
\hline
\end{tabular}

表 8 ナノコンポジットコーティング膜の各種ゴム加硫・成形での評価

\begin{tabular}{llcll}
\hline ゴム & 製品 & 成形方法 & & 評価 \\
\hline $\mathrm{Q}$ & リング & 圧縮 & 離型性が良い & 効果有り \\
$\mathrm{CR}$ & ジャバラ製品 & 圧縮 & 金型が錆びない & 効果有り \\
$\mathrm{EPDM}$ & ベタルゴム & 圧縮 & 離型性が良い & 効果有り \\
$\mathrm{SBR}$ & リング & 射出 & 極めて離型性が良い & 効果有り \\
$\mathrm{NBR}$ & 履物底 & 圧縮 & 離型が悪く, 擦り取る & 効果無し \\
$\mathrm{EPDM}$ & 車体製品 & 射出 & & 効果有り \\
$\mathrm{EPDM}$ & 創造製品 & 射出 & 2倍改善 & 効果有り \\
$\mathrm{EPDM}$ & 創造製品 & 射出 & 変更, 改善が必要 & 効果無し \\
$\mathrm{EPDM}$ & 印刷部品 & 圧縮 & 僅かな污れ & 効果有り \\
$\mathrm{NR}$ & & 压縮 & ブラシで取り除く & 効果無し \\
\hline
\end{tabular}

$\mathrm{Q}$ ：シリコーンゴム, $\mathrm{CR}$ ：クロロプレンゴム

EPDM : エチレン・プロピレンゴム

SBR：スチレン・ブタジエンゴム，

NBR：アクリロニトリル・ブタジエンゴム

$\mathrm{NR}$ : 天然ゴム 
くなり，疎水性になり，かつ硬くすることで効果が表れて いると考えられる。

ゴム用金型の表面処理として，ダイヤモンドライクカー ボン $(\mathrm{DLC}) ，$ 炭化クロム $(\mathrm{CrC})^{19)}$ ，および窒化クロム $(\mathrm{CrN})^{19)}$ のコーティングが優れていることが報告されて いる。 $\mathrm{CrC}$ は化学気相成長法 (CVD 法)で金型表面に成膜 され，離型性が極めて高く，耐食性に優れ，耐酸化性も $750{ }^{\circ} \mathrm{C}$ までと優れた性能を有するコーティング膜である. フッ素ゴムの加硫・成形において，硬質クロムめっきでは

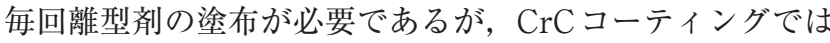
36 回まで離型剤を塗布することなく連続加硫・成形可能 である。また， CrN は物理気相成長法 (PVD 法)で金型表 面に成膜され，離型性が極めて良く，耐食性に優れ，耐酸 化性も $750{ }^{\circ} \mathrm{C}$ まで使用可能な優れた性能を有するコーティ ング膜である.

無機フィラーを含む液状フッ素ゴムの射出成形におい て，ゲートにDLCにより表面処理することで，金型ゲー トの摩耗が少なくなることにより金型耐久性が増し，離型 性も向上する ${ }^{20)}$ 。これで，製品の品質が向上し，金型交 換頻度が減少することからコストダウンが可能となる.

これまで行われた表面処理で金型污染に対する評価は長 所，短所があるが，その中でも金型污染防止，離型性の改 善には次の表面処理が有効である.

（1）セラミック処理 $(\mathrm{CrN}$ 被覆，ナノコンポジット被覆 など) ${ }^{19)}$

（2）イオン注入（硬質クロムめっき面への窒素，フッ素 イオン注入など $)^{21)}$

問題点：装置が高価である

（3）フッ素樹脂処理(フッ素樹脂被覆，フッ素樹脂の埋 め达み処理など) 22

問題点：耐久性，再コーティング性

これら金型の表面処理において，表面の特性と污染性と の関係は，水に対する接触角，表面硬度と污染度の関係 ${ }^{23)}$ から接触角が大きくなるほど，表面が硬くなるほど污染が 少なくなる。また，水に対する接触角，平滑さとの関係 ${ }^{23)}$ から接触角が大きく，表面が平滑になるほど污染が少なく なることが明らかにされている。これらの関係から，金型 污染が起こりにくい，起こらない金型表面としては，接触 角が大きいほど，すなわちはっ水性になるほど，表面がよ り平滑であるほど，また表面硬度が硬いほど摩擦係数が小 さく滑り易くなるほど金型污染が少なくなり，離型性が改 善されることが推察された。具体的な表面処理には， $\mathrm{CrN}$ 被覆，イオン注入による改質，ナノコンポジット被覆，耐 久性を改善したフッ素樹脂被覆が適している。

セラミックス被覆，フッ素樹脂被覆した金型は修理，再 被覆する場合にそれが可能であるかが使用する上で問題で あり，とくにフッ素樹脂被覆は耐金型污染性，離型性に優
れているが, 耐久性とともに再被覆が問題になっていると も言われている。

\section{3 離型剤}

従来，金型污染や型離れを改善するためには離型剤を使 用することで対応してきたが，外部塗布形離型剂を使用し た場合，その離型剂が污れの原因の一つになってきた。こ のため，メーカーでは離型剤の改良がなされている．また， 内部充てん形離型剂を使用する方法は離型性の改善には効 果があるが，成形後に塗料塗布，接着工程があれば使用す ることができないなどの問題がある.

外部塗布形離型剤は，コンベンショナルタイプ(自己犠 牲型) とセミパーマネントタイプ(半永久型)があり，污染 原因とならないのは後者である。半永久金型離型剤は低 VOCの溶剂を用いた溶剤型とVOCを含まない水系型があ り，それらは金型表面の微細なき裂を埋めることで表面を 滑らかにして摩擦係数を低下させ，小さな表面エネルギー で金型の污染物を蓄積しない特徴がある，最新の半永久金 型離型剤は $130{ }^{\circ} \mathrm{C}$ 以上では 30 秒以下で硬化し，通常の工 業的生産では50サイクルまでであったが，80-100サイ クルまで金型離型性を維持することによって生産性が向上 したと報告されている24)

離型剂のメーカーは数多くあり，これら離型剂から最適 な離型剤を選定するためには実際に使用してみて判断する ことが必要である。とくに，外部塗布形離型剤の選定につ いて, ゴム配合物はゴム種が同じであっても配合が異なり， 配合物の組成は全て異なるものと考えられることから, 実 際に使用するゴム配合物で離型剂を検証する必要がある。 また，選定されたとしても，金型表面への離型剂の均一な 塗布が金型污染に大きく影響し，金型表面での不均一な塗 膜では塗膜のない所，厚くなっているところは污染物の付 着, 離型剂の熱劣化が起こり，金型污染につながるもので ある．離型剤を表面に均一に塗布することが必要である.

離型剤の開発が行われており，ジメチルシリコーンオイ ルとペインタブル性シリコーンオイルを混合してなる離型 剂 ${ }^{25)}$ ，シリコーンオイル含有離型剤を用いて加熱加圧成形 した成形品 ${ }^{26)}$ ，シリコーン系ゴム成形用金型離型剤およ びこれを用いたシリコーン系ゴム成形体の成形方法 ${ }^{27)}$ ，ゴ

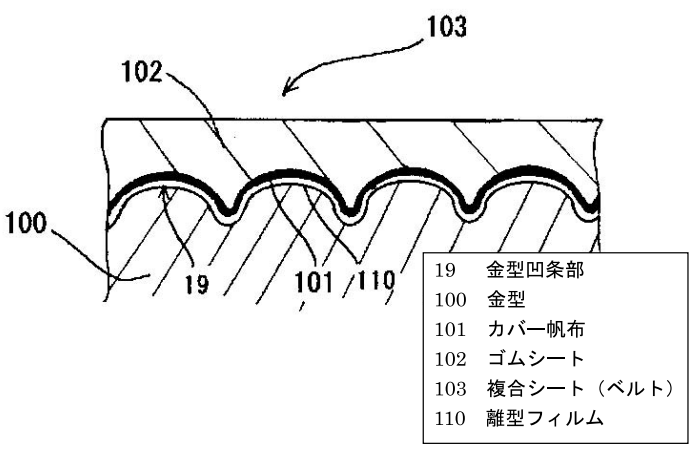

図 3 離型フィルムによる離型 
ルフボールの製造方法 ${ }^{28)}$ ，ゴム用離型剂およびゴム成形 方法 ${ }^{29)}$ ，粘性物質付着防止剂および金型成形品離型剤 30 ) などの例がある.

離型フィルムを使用する例があり，高負荷伝動ベルトに 用いるセンターベルトの製造方法において，凹凸形状を有 する金型上にポリオレフィンからなる離型フィルムを配置 して(図 3 ), カバー帆布, ゴムシートの順で積層して加熱 加圧することによって加硫して，その後脱型する ${ }^{31)}$.

\section{4 その他}

防着剤の乾燥が不充分であれば水分が残ることになり， それが金型污染の原因になっていることから，防着剤塗布 後の乾燥を充分に行うことが必要である.

間接加硫接着での金型污染防止は使用する接着剤の塗布 量とともに使用する接着剂の接着強度にも依存し, 接着強 度の測定方法およびどの程度の強度であれば污染を起こさ ないかが明らかにされている ${ }^{32)}$ 。また，発泡剤による金 型污染防止については加硫速度と発泡速度との関連，ゴム との相溶性が良好であることとその分散を良くすることが 必要である。

また，加硫・成形工程での加硫装置，とくに圧縮プレス 加硫ではプレス板が水平であることが必要で，ゴム試料に かかる荷重が異なると加硫が不均一になり，金型污染を引 き起こすことになる．昔のゴム技術者は常に水準器を携帯 していたことを聞いているが, 注意することが大切である.

\section{3. 金 型 洗 浄}

金型污染した金型は洗浄する必要があり，図 4 16) に示 すように金型を取り外して洗浄する方法あるいは金型を装 着したまま洗浄する方法で行われている．とくに前者の方 法はアルカリと酸洗浄が主体であったが，最近では環境問 題からプラズマ洗浄法, レーザー照射洗浄法, ドライアイ ス粒子噴射洗浄法が開発され，使用されている。これらの 方法は長所と短所があり，単に洗浄できるかどうかだけで

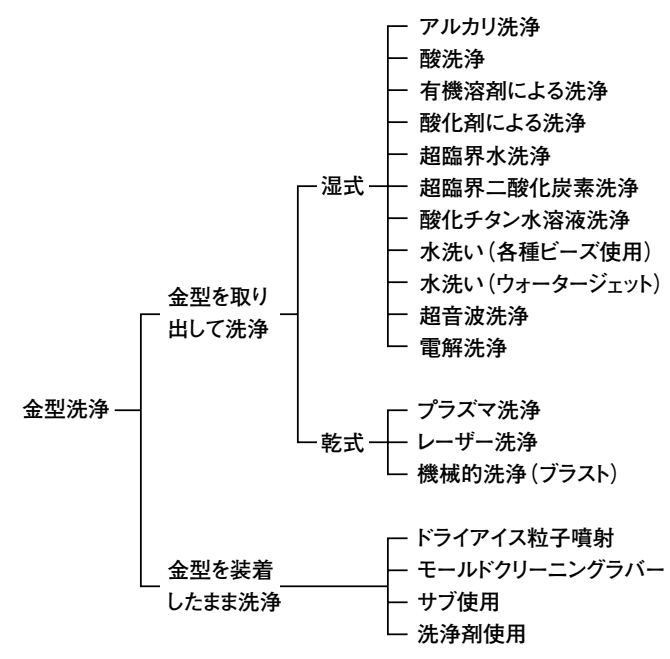

図 4 污染した金型の各種洗浄方法
はなく，使用されたゴム種，配合，金型の污れ具合などに よって使い分けされている.これらの洗浄方法について, 上嶋によってベンチテスト評価(洗浄品質の確保, 高い洗 浄生産性, 金型へのダメージレス)が行われているが33), 全ての項目を満足するものは見出されていないことが報告 されている. 今後, 金型の表面を傷めることなく, 後処理 の必要なウエットよりもドライな環境下での洗浄法の確立 が必要と考えられる。

タイヤ用金型の洗浄は, ショットブラスト法, 液体洗浄 法, レーザー照射洗浄法, プラズマ洗浄法, 超臨界水洗浄 法, ドライアイス粒子噴霧洗浄法, 超臨界二酸化炭素洗浄 法, 高密度プラズマ洗浄法, 酸化チタン水溶液洗浄法, 酸 化剂を用いる高温洗浄法などがある。

レーザー照射洗浄法は, YAGレーザーを使用した処理 であり，金型に与えるダメージがない反面，レーザー照射 の死角となる部分の污れが取れない。この改善として，金 型に付着した有機物に対して吸収率が大きく，また金型表 面に凹凸形状などのパターン溝に的確に照射することが可 能な短パルス $\mathrm{CO}_{2}$ レーザーを使用した洗浄システムがあ る34).

ドライアイス粒子噴霧洗浄法は，ブラストガンのノズル から発射されるペレット状のドライアイスを圧縮空気によ り金型表面に噴き付け，洗浄対象物にクラックが生じ，污 染物と金型との間にドライアイスが入り，気化する力を利 用してはく離する ${ }^{35)}$.

超臨界水洗浄法は高温 $\left(400{ }^{\circ} \mathrm{C}\right)$, 高圧 (40 MPa) の処理 であり，スリットベント内の洗浄効果も高いが，臨界水を 金型と接触させると, 金型表面を腐食させることなどの問 題がある. 超臨界二酸化炭素洗浄法 ${ }^{36)}$ は洗浄効果が認め られ，臨界点に近い条件では，洗浄時間に差があるものの， いずれの条件でも洗浄効果が認められる。 また, 臨界水と 同等程度の洗浄力 (洗浄効果) を得るには圧力が $20 \mathrm{MPa}$, 温度も $80{ }^{\circ} \mathrm{C}$ で十分であり，超臨界二酸化炭素洗浄法が有 効である。

この他に，酸化チタンの光触媒反応を利用した酸化チタ ン水溶液洗浄法 ${ }^{37)}$, 過酸化水素, オゾン, 次亜塩素酸, 硝酸，硫酸から選ばれる酸化剂を $0.3 〜 2.0$ 質量\%含む水性 洗浄液 ${ }^{38)}$, 強アルカリ系金型洗浄剂が開発されている ${ }^{39)}$. さらに，有機ホウ素高分子化合物を主成分とし，アミノ基 含有化合物と溶媒を配合した新しいタイプの洗浄剂が開発 されている ${ }^{40)}$.

モールドクリーニングラバーは保管中スコーチを起こし 保管安定性に課題があるものがあるが，スコーチを起こす 成分をマイクロカプセル化することで，洗浄成分によるス コーチを防止でき，保管時のブリードも防止できる．室温 に放置した後複雑な形状の金型に適用しても離型性を損な われることがない. 未加硫ゴムにマイクロカプセル化した 
アミン化合物を洗浄成分として添加したものが開発されて いる ${ }^{41)}$ 。また，ジエン系ゴムを $20 \mathrm{wt} \%$ 以上含有するゴム 成分 100 部と RO-A-H (R は炭素数 1 ～24 の脂肪族炭化水素 基，Aは炭素数 3 以上のオキシアルキレン基を $5 \%$ 以上含 むオキシアルキレン鎖)で表せる非イオン系界面活性剂を 0.5〜30wt \%, アミノアルコールを 2 20 部配合したも の ${ }^{42)}$ があり，特定構造の非イオン系界面活性剤を配合す ることで洗浄性能を向上している.

金型洗浄は污染物を取り除くことであり，少しでも残留 することで金型污染の種になるため，洗浄を完璧に行う必 要がある．金属表面，例えばステンレス鋼の表面洗浄をメ チルエチルケトンで行った場合とさらにアルカリで洗浄 (脱脂)を行った場合とでは，洗浄表面はXPS分析結果お よび接触角が異なり，洗浄方法の違いにより異なることが 明らかにされている ${ }^{43)}$. 従って, 金型の污れ(污染物)に よって洗浄効果が異なることが考えられ，金型に応じた洗 浄方法を確立することが必要である，そのためには，洗浄 後の評価 (洗浄度) を非接触リアルタイム表面洗浄度検査装 置や光沢計などで数值化することが必要である．また，洗 浄に使用する水に注意する必要があり，洗浄後，水蒸気あ るいはイオン交換水で洗浄しなければならない.

\section{4.お わりに に}

耐金型污染性，離型性などを改善するためには，ゴムか らの物質や離型剤などの，金型表面に付着している物質を できるだけ少なくすることと，金型表面にそれらの物質が 反応しないで，滑り易くすることが必要である，とくに， 金型表面はより平滑，はっ水性にすることが重要である. ここではゴム自体，各種配合剤，ゴム用金型の表面処理技 術，および離型剤の最近の動向，さらに金型洗浄技術につ いて紹介した。これら数多くの技術でも現時点では金型污 染の問題を解消できず，また新規洗浄装置，金型洗浄剤な どは金型に影響せず，コスト的にも満足できるレベルの洗 浄技術には到達していないのが現状である。これら技術を 技術開発するためにはユーザと金型，処理メーカー，洗浄 機のメーカーなどの綿密な連携が必要である。

今後, 高精度なゴム製品の成形に対応できる耐金型污染, 離型性，金型表面処理，金型表面の性状(平滑さ，接触角 など)に関する技術が求められ，ナノコンポジットコーテ イング法の開発，ナノオーダーの加工技術などミクロンか らナノへのナノテクノロジーなど最新技術が必要となると 予測される。また，地球環境保全に対応した金型材料，金 型表面処理技術などの開発が期待される．さらに，近年プ ラスチック，ガラス，セラミックス表面に耐污染性(污れ にくい，污れが落ち易い)を付与するため親水化，はっ水 化がフッ素系，シリコーン系処理など行われており，その 技術の活用が期待される.

\section{References}

1) Yamaguchi, K.: "Gomu • Elastomer You Kanagata Gijyutsu Q\&A”, Kougyo Chosakai, Tokyo, p.160 (2006)

2 ) Yamaguchi, K.: ibid., p.166 (2006)

3 ) Yamaguchi, K.: ibid., p.162 (2006)

4) Yoshimura, T.; Nagamori, H.: Nippon Gomu Kyokaishi, 78, 51 (2005)

5 ) Terada, K.; Omiya, H.; Tsujimura K.; Misumi, Y.: Jpn. Kokai Tokkyo Koho 2005-60546 (2005)

6 ) Mizumoto, K.: "Gomu • Elastomer You Kanagata Gijyutsu", Kougyo Chosakai, Tokyo, p.239 (2004)

7 ) Hara, J.: Polymer Digest, 46 (4), 57 (1994) ; Sumitomo Kagaku, 1994 (2), 20 (1994)

8 ) Nishizawa, H.: "Gomu • Elastomer You Kanagata Gijyutsu", Kougyo Chosakai, Tokyo, p.85 (2004)

9 ) Kadota, T.: Jpn. Kokai Tokkyo Koho 2003-226780 (2003)

10) Van Baarle, B.: Rubber World, 231 (3), 25 (2004)

11) Nordsiek, K. H.; Wolpers, J.: Kautsch. Gummi Kunstst., 47, 319 (1994)

12) Dohi, H.: Nippon Secchaku Gakkaishi, 42, 533 (2006)

13) Heideman, G.; Noordermeer, J. W. M.; Datta, R. N.: Rubber Chem..Technol., 79, 561 (2006)

14) Yamaguchi, K.: "Gomu • Elastomer You Kanagata Gijyutsu Q\&A”, Kougyo Chosakai, Tokyo, p.98 (2006)

15) Kubota, R.; Sudou, M.: Jpn. Kokai Tokkyo Koho 2006-347098 (2006)

16) Yamaguchi, K.: Nippon Gomu Kyoukai, $142^{\text {nd }}$ Gomu Gijyutsu Symposium Text, p.62 (2007)

17) King, D.; Kammerer, K.; Lefebvre, L.; Renggli, E.: Rubber World, $233(3), 16(2005)$

18) Holocher-Ertl, M.; Passler, T.: Gummi Fasern Kunstst. 59, 91 (2006)

19) Toyo Eitekku : Gijyutsu Shiryou (2007)

20) Osawa, Y.: Jpn. Kokai Tokkyo Koho 2000-313034 (2000)

21) Yamaguchi, K.: "Gomu • Elastomer You Kanagata Gijyutsu", Kougyo Chosakai, Tokyo, p.187 (2004)

22) Nippon Puroton : Gijyutsu Shiryou (1995)

23) Yamaguchi, K.: "Gomu • Elastomer You Kanagata Gijyutsu Q\&A", Kougyo Chosakai, Tokyo, p.174 (2006)

24) Menting, K.; Hensel, M.: Paper presented at the $170^{\text {th }}$ Meeting Rubber Div. Am. Chem. Soc. (2006)

25) Watanabe, T.: Jpn. Kokai Tokkyo Koho 2003-48218 (2003)

26) Yamakawa, K.; Watanabe, J.: Jpn. Kokai Tokkyo Koho 2002$154121(2002)$

27) Nobutani, N.; Hanchi, H.; Yamakawa, N.; Kusama, M.: Jpn. Kokai Tokkyo Koho 2004-82433 (2004)

28) Moriyama, K.; Sasaki, T.; Iwami, S.; Kikuchi, M.: Jpn. Kokai Tokkyo Koho 2004-290315 (2004)

29) Kawasaki, H.; Iwasaki, S.: Jpn. Kokai Tokkyo Koho 2006224426 (2006)

30) Satou, N.; Satou, T.: Jpn. Kokai Tokkyo Koho 2003-221587 (2003)

31) Itoh, T.: Jpn. Kokai Tokkyo Koho 2004-106545 (2004)

32) Sugiura, T.: Jpn. Kokai Tokkyo Koho 2002-243629 (2002)

33) Kamishima, K.: Nippon Gomu Kyoukai, $142^{\text {nd }}$ Gomu Gijyutsu Symposium Text, p.1 (2007)

34) Kokufuda, K.; Mitsui, S.; Sakakida, M.: Jpn. Kokai Tokkyo Koho 2008-62633 (2008)

35) Gurin Tekku Japan : Gijyutsu Shiryou (2008)

36) Sugata, M.: Jpn. Kokai Tokkyo Koho 2005-161150 (2005)

37) Sugata, M.: Jpn. Kokai Tokkyo Koho 2005-178025 (2005)

38) Nagase, K.; Sarumaru, S.; Nakai, M.; Masudo, K.; Watanabe, K.: Jpn. Kokai Tokkyo Koho 2006-62253 (2006) 
39) Miki, S.; Kumagai, S.: Jpn. Kokai Tokkyo Koho 1999-90938 (1999)

40) Satou, N.: Jpn. Kokai Tokkyo Koho 2003-291152 (2003)

41) Nishi, Y.: Jpn. Kokai Tokkyo Koho 2002-137232 (2002)

42) Kitahara, K.; Yanagisawa, K.: Jpn. Kokai Tokkyo Koho 2001293730 (2001)

43) Hirahara, H.: "Syuuki Gomu Gijyutsu Kousyuukai", Nippon Gomu Kyokai Kansai-shibu, p.43 (2008)

\section{日本語表記参考文献}

1 ）山口幸一：ゴム・エラストマー用金型技術 Q \& A, 工業調查会, 東京, p.160 (2006)

2 ) 山口幸一：ゴム・エラストマー用金型技術 Q \& A, 工業調査会, 東京, p.166 (2006)

3 ）山口幸一：ゴム・エラストマー用金型技術 Q \& A, 工業調查会, 東京, p.162 (2006)

4 ）吉村 務，永森弘康：日本ゴム協会誌，78，51（2005）

5 ）寺田健志，大宮浩，辻村和也，三隅好三：特開 2005-60546 (2005)

6 ) 水本清文：ゴム・エラストマー用金型技術, 工業調査会, 東京, p.239 (2004)

7 ) 原寿三男 : ポリマーダイジェスト, 46(4), 57(1994); 住友化学, $1994(2), 20$ (1994)

8 ）西澤仁：ゴム・エラストマー用金型技術, 工業調査会, 東京, p.85 (2004)

9 ) 角田友和 : 特開 2003-226780 (2003)

12）土肥英彦：日本接着学会誌，42，533 (2006)

14）山口幸一：ゴム・エラストマー用金型技術 Q \& A, 工業調査会, 東京, p.98 (2006)

15）久保田朗仁，須藤盛皓：特開 2006-347098 (2006)

16）山口幸一：第 139 回ゴム技術シンポジウム テキスト, p.62
(2007)

19）トーヨーエイテック株：技術資料 (2007)

20）大澤康久：特開 2000-313034 (2000)

21）山口幸一：ゴム・エラストマー用金型技術, 工業調査会, 東京, p.187 (2004)

22）秼日本プロトン：技術資料（1995）

23）山口幸一：ゴム・エラストマー用金型技術 Q \& A, 工業調査会, 東京, p.174 (2006)

25）渡辺孝之：特開 2003-48218（2003）

26）山川賀津人，渡邊次郎：特開 2002-154121（2002）

27）延谷典行, 畔地秀一, 山川直樹, 草間誠：特開 2004-82433 (2004)

28）森山圭治，佐々木隆，岩見聡，菊池正明：特開 2004-290315 (2004)

29）川崎弘志，岩崎進：特開 2006-224426（2006）

30）佐藤成勝，佐藤常介：特開 2003-221587 (2003)

31）伊東武彦：特開 2004-106545（2004）

32) 杉浦隆典：特開2002-243629 (2002)

33）上嶋桂二：第139回ゴム技術シンポジウム テキスト, p.1 (2007)

34）国府田京司，三井悟，榊田正之：特開 2008-62633（2008）

35）(株)グリーンテックジャパン：技術資料 (2008)

36）姿通博：特開 2005-161150（2005）

37) 姿通博：特開 2005-178025 (2005)

38）長瀬佳之, 猿丸正悟, 中井美行, 増田薰, 渡辺克充 : 特開 2006$62253(2006)$

39）三木茂機，熊谷定蔵：特開平11-90938 (1999)

40) 佐藤成勝：特開 2003-291152 (2003)

41）西 裕一：特開 2002-137232 (2002)

42）北原宏太，柳澤和宏：特開 2001-293730 (2001)

43）平原英俊：秋季ゴム技術講習会，日本ゴム協会関西支部，p.43， (2008) 